Information for citation:

Emelkina I. A. Sovremennye modeli chastnopravovykh ogranicheniy prava sobstvennosti na zemel'nuyu nedvizhimost' [Modern Models of Private Law Restrictions on the Right of Ownership to Landed Estate]. Vestnik Permskogo Universiteta. Juridicheskie Nauki - Perm University Herald. Juridical Sciences. 2018. Issue 39. Pp. 74 98. (In Russ.). DOI: 10.17072/1995-4190-2018-39-74-98.

UDC 347.2 .3

DOI: 10.17072/1995-4190-2018-39-74-98

\title{
MODERN MODELS OF PRIVATE LAW RESTRICTIONS ON THE RIGHT OF OWNERSHIP TO LANDED ESTATE
}

The article was prepared as part of a scientific project supported

by the Russian Foundation for Basic Research (project No. 17-03-00691)

\section{A. Emelkina}

National Research University "Higher School of Economics"

20, Myasnitskaya st., Moscow, 101000, Russia

ORCID: 0000-0002-0071-0163

ResearcherID: W-2836-2017

E-mail: iemelkina@yandex.ru

Introduction: the article considers various legal models of private law restrictions on the ownership of land. In the context of the formation of a single civil law institute of neighbor law, it is necessary to form a model of private law restrictions on property rights corresponding to modern social and economic relations. In different legal systems, their own legislative models of neighbor law have been developed. With the introduction of new technologies, modern types of industrial production, development of opportunities for using space over private real estate for various purposes, there appear new concepts of neighbor law. In this regard, the study of a set of theoretical and legal issues concerning neighbor law is of considerable significance. Purpose: to develop an understanding of the legal models of private law restrictions on the right of ownership to real estate in European countries and the United States, based on the analysis of scientific sources, various legal doctrines, laws of individual countries, as well as judicial practice. The leading method to investigate this problem is the comparative legal one, which allows us to comprehensively consider the legal institutions of neighbor law in different countries and to identify the most general patterns of the development. Along with the comparative legal method, we also used the methods of objectivity, from the abstract to the concrete and from the concrete to the abstract, empirical methods of comparison, description, interpretation, theoretical methods of formal and dialectical logic. Results: the principles on which restriction on property rights in foreign legal systems is based are presented, the model of neighbor law proposed for implementation in the $19^{\text {th }}$ century is shown, various theoretical models of neighbor law in domestic and foreign law are analyzed, the author's model recommended for application to improve legislation on the ownership of real estate is presented. Conclusions: the paper justifies differences in the approaches of American and European law in the formation of restrictions on property rights, and also the absence of grounds for the dominance in the countries of the post-Soviet space of the American model of restrictions on the ownership of private property. The paper substantiates the criteria for the differentiation between public and private law regulation of neighborly relations, the dominance of the norms of civil law in neighbor law, the possibility of changing legal restrictions on property rights in the interests of a neighbor by an agreement establishing the real right of a servitude type, grounds for referring to the right of the necessary road in the German legal order. The materials of the article are of practical value in determining the legal policy for the development of legislation on restrictions on the right of ownership to land in the interests of neighbors in the context of the reform of Russian civil law.

Keywords: real estate; land; land surveying; ownership; property rights; neighbor law; neighbor; servitude; development; land boundaries; land cadaster; landowner; restrictions; rights of neighbors; real right; divided property 
Information in Russian

\section{СОВРЕМЕННЫЕ МОДЕЛИ ЧАСТНОПРАВОВЫХ ОГРАНИЧЕНИЙ ПРАВА СОБСТВЕННОСТИ НА ЗЕМЕЛЬНУЮ НЕДВИЖИМОСТЬ}

Публикация подготовлена в рамках поддержанного РФФИ научного проекта (проект № 17-03-00691)

\section{И. А. Емелькина}

Доктор юридических наук, доцент,

профессор кафедры гражданского и предпринимательского права

Национальный исследовательский университет «Высшая школа экономики»

101000, Россия, г. Москва, ул. Мясницкая, 20

ORCID: 0000-0002-0071-0163

ResearcherID: W-2836-2017

E-mail: iemelkina@yandex.ru

Введение: статья посвящена анализу различных правовых моделей частноправовых ограничений права собственности на земельную недвижимость. В условиях формирования единого гражданско-правового института соседского права необходимо формирование модели частноправовых ограничений права собственности, соответствуюшей современным социально-экономическим отночениям. В различных правопорядках выработаны собственные законодательные модели соседского права. С введением новых технологий, современных видов промышленного производства, развитием возможностей использования пространства над частной недвижимостью в разнообразньх целях предлагаются новые концепции соседского права. В связи с этим изучение комплекса теоретико-правовых вопросов соседского права является значимыл. Цель: сформировать представление о правовых моделях частноправовых ограничений права собственности на недвижимость в европейских странах и США на основе анализа научных источников, различных правовых доктрин, законодательства отдельных стран, а также судебной практики. Ведущим методом в исследовании данной проблемь является сравнительноправовой, позволяющий комплексно рассмотреть правовые институты соседского права различных стран и выявить наиболее общие закономерности развития. Наряду со сравнительно-правовым методом достижение поставленных задач возможно на основе применения методов объективности, от абстрактного к конкретному и от конкретного к абстрактному, эмпирических методов сравнения, описания, интерпретации, теоретических методов формальной и диалектической логики. Результаты: в статье представлены принциипы, на которых основано ограничение права собственности в зарубежных правовых системах, показана предлагаемая к внедрению в ХІХ столетии модель соседского права, проанализированы разнообразные теоретические модели соседского права в отечественном и зарубежном праве, представлена авторская модель, рекомендуемая к применению при совершенствовании законодательства о праве собственности на недвижимость. Выводы: обоснованы отличия в подходах американского и европейского права при формировании ограничений права собственности, об отсутствии оснований для доминирования в странах постсоветского пространства американской модели ограничений права собственности на частную недвижимость. Аргументированы критерии разграничения публичного и частноправового регулирования соседских отношений, доминирования в соседском праве норм гражданского законодательства, возможности изменения законных ограничений права собственности в интересах соседа соглашением, устанавливающим вещчное право сервитутного типа, основания для обращзения к известной в германском правопорядке права необходимой дороги. Материаль статьи представляют практическую ценность при определении правовой политики формирования законодательства об ограничении права собственности на земельные участки в условиях реформы российского гражданского права.

Ключевые слова: недвижимость; земельный участок; межевание; право собственности; соседское право; сосед; сервитут; право застройки; границы земельных участков; земельный кадастр; землевладелец; ограничения; соседские права; вещное право; разделенная собственность 


\section{Introduction}

Restrictions on the private ownership of landed estate have long been known in legal regulation. They were recognized as independent restrictions on the private owner's rights even by Roman lawyers. In Roman law, restrictions on property rights were divided into restrictions on property rights in public interests and those in private interests. V. M. Khvostov stated: "Considerations on the needs of people surrounding the owner and on the interests of the state or community to which the owner belongs always cause the law to limit the owner's freedom within certain boundaries" $[18$, p. 231]. When developing their legislation, civil law countries, based on the reception of Roman law, are still guided by the Roman postulates, along with the national customs and traditions established over centuries. Nowadays, restrictions on property rights are known to many developed legal systems, and they are classified into public law and private law restrictions on property rights.

In particular, when the owner of a real estate is using the land, they are to comply with the procedure established by the public land legislation on land zoning and on its authorized use; when an owner is mining commonly occurring minerals, they are to follow the rules of the subsoil legislation; usage of groundwater at the land is regulated by the water legislation; construction is to comply with the rules of the town-planning legislation concerning the distance of objects from the land boundaries and from other structures, the height of buildings, the structure of foundation, and the features of the roof; usage of the boundary and the neighboring territory is regulated by the rules on the land cadastre; construction and use of water and gas pipelines, electric networks and other communications supporting normal operation of the house should comply with the legislation rules on gas, heat and power supply. In addition, the activities of the owner are subject to the regulation of the legislation on environmental protection, which establishes bans on harmful emissions into the atmosphere and on the use of devices emitting radiation. These times, life of a landowner is also regulated by the legislation on the use of aircrafts (drones), the wireless Internet used via specially allocated space, legislation on the use of solar energy when assembling solar cell batteries [22; 33; 34].
Obviously, the rules established by the mentioned legal acts prohibit certain activities and also oblige the owner to act in an established manner; they are aimed at protecting different areas of the life of society (environmental safety, health of citizens, development of economic relations etc.), providing proper functioning of the public authorities and law enforcement. Taken together, the mentioned rules of public acts constitute one significant sphere which is known in legal doctrine as the restriction on property rights in the public interest.

Furthermore, exercising the right of ownership, a landowner is constantly in contact with the ownership right of the neighboring land owners, and accordingly their actions are not to violate the rights and interests of the neighboring real estate owners. The sphere of legal relations between neighbors has traditionally been regulated by an independent subbranch in law through the agency of the private law regulation, and is referred to as neighbor law (private law restrictions on property rights).

Neighbor law is regulated as a type of private law restrictions on property rights in $\S 906-924$ of the German Civil Code (Deutsches Bürgerliches Gezetzbuch (BGB)), Art. 669-701 of the Swiss Civil Code of 1907 (Schweizerisches Zivilgesetzbuch (ZGB)), cl. $2 \S 364-\S 364$ b of the Austrian Civil Code (Österreich Allgemeines Bürgerliches Gezetzbuch (ABGB)), the French Civil Code (legal easements (Art. 640-685-1), Art. 1013 of the Czech Republic Civil Code [6, p. 82]. In some countries, there have been introduced special laws concerning neighbors' rights, for instance, the law No. 15 "On neighbors" from June 16, 1961 in Norway, the law "On some neighborly relations" in Finland [35, p. 80]. In some post-Soviet countries, there have also been restored the classic rules on neighbor law [27]. Restrictions on property rights in favor of neighbors are fixed in art. 377-394 of the Moldova Civil Code, art. 10821129 of the Latvia Civil Code, art. 174-182 of the Georgia Civil Code, art. 195-205 of the Civil Code of Turkmenistan.

Independent neighbor law has not been introduced into the Russian law so far. Despite the land real estate being in circulation and development of the institution of private property, the relations between neighbors are not a subject to any special 
legal regulation except for acts of public legislation, whose main purpose is known to be the protection of public interests. The existence of an independent neighbor's interest as an object of protection, as well as of independent rights and duties of a neighbor in relation to landed estate are ignored in the national law. Because of the absence of special legal regulation, neighbor conflicts are often impossible to resolve only on the basis of public law acts.

Introduction of neighbor law was suggested in Federal Law "On Amending Parts One, Two, Three, and Four of the Civil Code of the Russian Federation and Certain Legislative Acts of the Russian Federation", adopted by the State Duma of the Russian Federation in the first reading in 2002, and brought by the President of the Russian Federation to the State Duma on April 3, 2012. The Presidential Council of the Russian Federation prepared the Concept for the Development of Civil Legislation of the Russian Federation before the bill [8]. A real struggle of various political forces occurred around the draft. Its section "Property law", which provided for the introduction of new provisions on the legal regulation of property relations regarding land and other real estate, met the greatest resistance. This bill as a whole was not supported and was further fragmented into several separate projects, most of which were adopted and put into effect in Russia. The part of the project devoted to property law is known to have not been adopted yet.

Such rejection of classic restrictions on property rights can be partially explained by the destruction of civilized rules for the use of landed estate in the last century, and by the formation of a special administrative regime in this field in Soviet law. The absence of true private law principles in that period did not allow for developing a system of private restrictions on property rights, known as neighbor law. The centralized regulation of land use relations created strict rules of conduct established in administrative, town-planning, water, forestry, and land legislation. The private interest was not at the forefront. The main purpose of regulation was to protect public and state interests, including the law enforcement. The almost seventy-year absence of the right of ownership to landed estate contributed to the formation of a special branch of land law and the concentration of the rules concerning the exercise of rights to land in land legislation. The refusal of the monopoly of the state ownership of land and other real estate at the end of the last century required the restoration of classical private principles in the legal regulation of land ownership, because the private interest and the private property are two related concepts. Today, there is an urgent need to fill the gap in the legislative regulation of relations between owners of neighboring lands, which is called "neighbor law" in European and American law, or Nachbarrecht (Germany, Austria and Switzerland), and law of neighbors - in the USA.

Despite the increased interest to the problems of the neighbor law theory in the national doctrine, as of today there have not been any comprehensive research conducted in this area and taking into account the theory and practice of foreign states in this sphere.

In the national doctrine, there are both a gap in the study of neighbor law and various contradictions regarding the possibility of introducing its elements. Therefore, the purposes of this article are:

a) to show the legislative models of restrictions on property rights in the interests of neighbors existing in foreign law (various European states, as well as the USA);

b) to analyze doctrinal models of restrictions on property rights, to solve current problems;

c) to design a model that can be efficient in the Russian socio-economic conditions.

\section{The Legal Model of the Private Property Ownership Restrictions in European Countries (Germany, Austria, Switzerland, Finland, France, etc.)}

The German researchers H. Prütting and G. Schwab note the current relevance of studying neighbor law for German civil law. They write: "Legal rules on neighbor law originate from the ancient time. However, these rules are to adapt to changing circumstances. First of all, modern 
industrial development posed new challenges to the legal system. Accordingly, modern legislation on neighbors' rights should also answer the question concerning an owner using their property - whether the owner's interest should be more important or they should give way to the interests of trade, business or other activities. The recent changes cause the revision of the requirements on environmental protection in terms of regulation of neighbors' rights. Accordingly, it is necessary to find an answer whether laws on neighbor law are able to protect against environmental pollution and if they are - to what extent.

According to Art. 124 of EGBGB (Federal Law on Environmental Protection), property rights can also be limited in the exercise of neighbors' rights by public law. The state widely used this, for example, in case of regulation of land boundaries, construction of fences, distance between plants, etc. The practical impact of all these rules is admitted" [31, p. 83].

Thus, the issues of neighbor law have not lost their relevance in German literature, and they require further development, including the problems of environmental protection as well as balancing the interests of neighboring land owners when they are using their private property for business purposes.

In German law, special attention is paid to restrictions on property rights. They are divided into norms of public and private law. The provisions on the restriction of the private property ownership are contained in many public legal acts of the Federal Republic of Germany: in the Law on the Resettlement System and Land Use Planning of April 8, 1965, the Construction Code of August 27, 1997, building regulations of different lands, the Reich Nature Protection Act of June 26, 1935, the Law on the Protection of the Environment and Landscape Development Management of December 20, 1976, the Waste Disposal Law of August 27, 1986, etc. [17, p. 83].

Much attention is paid to private law restrictions on property rights both by legislation and by the German doctrine. An important place is occupied by the rules of the so-called neighbor law, i.e. restrictions on property rights in the interests of neighbors.

O. F. Gierke wrote the following: "Neighbor law establishes restrictions by virtue of which the owner is obliged either to refrain from a certain use of land or to tolerate the actions of another person a neighbor in relation to the land that is in their own ownership" [23, p. 418].

In the German Civil Code, norms on neighbor law are embodied in general provisions, establishing rules concerning the impact on the land, and special rules for the regulation of certain neighbor relations.

The general provisions set out the rules on the interaction of neighbors based on their obligation to "tolerate" the impact from another land within the established limits (immissions), and also prohibit certain actions of the owner on their own land in the interests of the neighbor (for example cl. 1 $\S 206$ BGB). The general part also lists the criteria of the admissible impact from the neighboring land (cl. $2 \S 906$ BGB).

The special rules fix norms regulating some certain kinds of interaction between neighbors both within the admissible impact and beyond these limits. This part of the neighbor law contains norms regulating the relationship of neighbors in case of unauthorized construction on another person's land; in case of a threat of a building's collapse; when determining the boundary; in case of the construction of boundary facilities, landmarks and their maintenance; norms on the right to "the necessary road", etc. (for example, § 907-923 BGB). In the special part, there are also presented regulations on certain types of neighboring relations and possible ways of resolving neighbor disputes [6, p. 87].

The analysis of the legislation of continental Europe shows that the content of neighbor law is considered through bans on certain actions of a neighbor towards their land, establishment of the obligation "to tolerate" some impacts from the neighbor's land, as well as norms aimed at prevention of disputes between neighbors and settlement of already developed ones. In particular, German law regulates such relations between neighbors that arise in the course of determination of the land boundaries, construction and maintenance of fences, establishment of landmarks, it establishes the rights of the neighbor in case of unintentional construction another person's land, etc.).

Unlike German law, the Swiss Civil Code (ZGB) is based on a more detailed regulation of neighboring relations. In particular, the rules on the 
use of common water sources and construction on a neighboring land are specified in more detail; the rule "to tolerate" the impact from the neighbor's land is more specific. In this code, there is no such a clear division of the neighbor law norms into the general provisions and the special rules; however, they are clearly divided into groups according to the subject of regulation: neighbors' rights in relations on construction on a neighboring land; neighbors' rights when there is business conducted on the land; rights and duties of neighbors concerning the maintenance of the common fence, trees and bushes on the boundary, etc.; the right to establish the necessary road or to conduct energy supply lines, to supply water through the neighboring land, etc.; neighbors' rights in relation to water sources. Even the legal consolidation of the traditional neighbor obligation to tolerate the "non-material impact" fixed in the Swiss Code has a significant specificity in the form of obligation for the neighbor from whom the impact is exerted to stay within the specified limits ( $\$ 684$ ZGB) [6, p. 89].

In the Austrian Civil Code (ABGB), neighbor law is regulated by cl. $2 \S 364-\S 364 \mathrm{~b}$. However, even such a little regulation has already generated a great number of legal precedents, which allow us to say that the Austrian legal mechanism for regulating neighbors' rights is similar to the German one [24, pp. 62-75]

The content of "neighbor law" according to the European model. The basic rule is embodied in cl. 1 art. $\S 906$ of the BGB. It establishes that a land owner cannot prohibit the impact of gases, vapors, smells, smoke, soot, heat, noise, vibration and other similar impacts coming from the neighboring land, if they do not influence or influence insignificantly the use of their land. An impact is considered to be insignificant if it does not exceed the limits and norms established by laws or regulations.

In addition, par. $2 \S 906$ of the BGB proceeds from the statement that similar rules are applied if a significant impact is caused by the use of the neighboring land that is considered to be usual according to the local conditions and cannot be stopped by measures economically feasible for users of this kind. If, in accordance with this, the owner has allowed an impact on their land, they have the right to demand an equivalent monetary compensation from the user of the neighboring land, on condition that this impact violates their land use considered to be usual according to the local conditions, or prevents the receipt of income from the land more than it is accepted.

The Austrian BGB (cl. 2 § 364) establishes the rule according to which a land owner cannot prohibit the neighbors from making impact on their territory by sewage, smoke, gases, heat, smell, noise, vibration, etc. coming from the neighboring land, if it does not exceed the established limits, and also does not significantly affect the usual use of the land [6, pp. 89-91].

$\S 364 \mathrm{a}$ of the ABGB establishes the rule that if the violation is caused by the operation of a structure officially permitted on the neighboring land, then the landowner has the right to apply to the court to seek compensation for the damage, even if the damage is caused by circumstances that have not been taken into account within the administrative proceedings [26].

As for the Swiss ZGB, there is also a similar rule, but it is established in relation to the exercise of ownership on the land where an enterprise operates.

According to cl. 1 art. of the 684 ZGB, everyone is obliged to refrain from undue influence on the rights of neighbors when they are exercising their ownership right, in particular when they are running business on their land. In particular, all the impacts in the form of smoke and soot, unpleasant odor, noise, or vibration, those harmful and unjustified by the location and the nature of the land or by local customs, are forbidden.

Thus, the mentioned legislative rules of different countries are based on a common doctrine that allows for two types of impact on a neighboring land: material impact (solid and liquid substances) and non-material impact (smoke, smell, soot, etc.)

German and the Austrian laws do not allow for a rough impact (stones, trees, landslides, water, large animals, etc.).

In Finland, rights of neighbors are protected not only by building codes and rules, but also by other laws, for example by the special law "On Certain Relations Between Neighbors". Although some provisions of this law are outdated, they are still applied in practice. In particular, the law states that the placement of a stable, a shed and a toilet should not be inconvenient for a neighbor. Also, pruning of roots and branches protruding from the neighboring land is permitted. 
The ground excavation is allowed only in such a way that is not harmful for the neighbor's house. It is also necessary to ensure that buildings and equipment will not fall on the territory of the neighbors. The general rule is the ban on such use of the property and the house which causes unacceptable harm to the neighbor, for example from soot, pollution, dust, smell and noise. The general recommendation is to prevent such actions which can cause inconvenience to neighbors, or they are better to be agreed on in advance [14, p. 60].

\section{Legal Model of Property Rights Restrictions in American Law}

In American literature, it is noted that the problems of neighbors' interaction are aggravated by such modern tendencies as "the shrinking space of today's world", and "the transiency of society" [20, p. 5]. Regarding the level of the neighbor law development in American practice, Emily Doskow and Lina Guillen, the authors of the popular American book on neighbor conflicts, write: "Disputes between neighbors are older than any laws ever passed. They concern space, property, money and human personalities. The shrinking space of today's world exacerbates our problems, as does the transiency of society. Often, we simply do not know our neighbors and are too busy and too tired to make an effort. Congestion and fear of crime tend to make us isolate ourselves. Much of the law - statutes and court decisions - addressing neighbor disputes is quite old. Relatively few neighbor disputes reach the courts today. There are several reasons for this. Many of the laws are long settled and disputes are resolved early on. And today when a subdivision springs up, the boundary lines are set by licensed surveyors. When property changes hands, a title company insures the Buyer and the title. If a difficulty arises, the new owner can usually go to the insurance company rather than to court. One obvious reason that neighbors don't take quarrels to court (except small claims court) is the enormous cost. An argument over a tree is often simply not worth the high fees charged by lawyers. It is one thing to hate the roots from your neighbor's tree that clutter your yard, and quite another to put out $\$ 5,000$ and several years in court to try to change the situation" [20, pp. 5-6].
Relations between neighbors have particular importance in American law. However, such features of American law as the dominance of judicial precedent in the law source system, the presence of trust property and the absence of the real right institution could not but influenced neighbor law. Therefore, in American law the main rules regulating relations between neighbors are the rules established in public legislation of the USA or of individual states, as well as in that of a separate locality.

The system of property rights in American law is quite distinctive. The rights of property maintenance are identified with property rights, and are considered its varieties and, in this capacity, can be considered a substitute of the property rights of the continental law. Within these rights, there can be divided a property right analogous to the continental one (ownership), mediated in relation to the land property by the title, referred to as the freehold title, and other property rights similar to that of the Romano-Germanic legal system: the right of pledge, easement, etc. [16, p. 25].

The history of the development of restrictions on the property right in American law is quite contradictory. In the $19^{\text {th }}$ century, landowners had an absolute freedom of ownership in order to assimilate intensively the useful properties of the land, to form a market for land assets protected from government interference and freely circulating. The US industrialization and the development of lands rich in natural resources provided ground for the freedoms granted by the US government to industrial landowners, which resulted in the active development of industrial production in comparison with the agrarian sector. On the other hand, the intensive use of land was associated with causing harm to neighbors and surrounding communities, as well as environmental degradation. The rights of communities, as well as those of small farmers, were significantly impaired. The significant damage to the natural environment was caused as a result of intensive use of land for industrial production and extraction of natural resources. That is why in the late $19^{\text {th }}$ early $20^{\text {th }}$ century the US government decided to change the law on property in terms of creating a system of its limitations [20, p. 5]. 
Obviously, the above excursion into the history of the land ownership restriction development shows that the main emphasis has been placed on the need to restrict the rights of big landowners, i. e. it concerns the so-called restrictions on property rights in the public interest. Meanwhile, the law of the United States also has the restriction on property rights in private interests. However, it should be noted that this institution of American law is very different from the classical similar institution of the continental law. The common thing between these institutions is the goal to create such regulation of relations between neighbors which is based on their peaceful coexistence, minimization of neighbor disputes, their regulation in pre-trial order, involving court only in exceptional cases. However, in the given legal models the means for achieving this goal are different.

Despite the absence of a special regulation of neighbor law in an independent act of the US civil legislation, there are many rights, privileges, and duties, and as of today there has been formed a system of neighbors' rights regulation, which is called "Law of Neighbors" or "Neighbors Law".

It is possible to distinguish several independent subsections in the American Law of Neighbors. In particular, these are neighbors' rights arising in the case of noise from a neighboring land, neighbors' rights to common boundaries, keeping animals and construction of fences $[20 ; 21]$.

The relations in the mentioned spheres are regulated mainly by statutory acts of the states, local self-governments, containing administrative norms aimed at law enforcement in a certain locality, imposing strict sanctions, both administrative and criminal.

For example, noise from a lawn mower, construction machinery, car, barking or howling dog exceeding the limits established by law violate the noise legislation. In many cities, there are local rules limiting the decibel level. With the help of electronic equipment for noise measurement, an owner can determine whether there are grounds to protect their rights and to punish a neighbor [20, p. 16].

Most local resolutions include the elements of violations of the so-called "quiet time" and establish responsibility for such actions. As a general rule, in many states there are prohibited loud sounds in the period from 11:00 p.m. to 7:00 or 8:00 a.m. on weekdays and from 11:00 p.m. or 00:00 to 8:00 a.m. on Saturdays, Sundays and public holidays. Some cities establish an evening limit at 9:00 p.m. or even $6.00 \mathrm{p} . \mathrm{m}$. This means that if any noise is too loud during this time, it is recognized to be above the permissible limit. Cities that use the decibel system also reduce the noise limit during these hours. These "quiet hours" can vary from one district to another within a city, depending on the zoning for a particular location. For example, in a residential area the morning limit hour can be 8 a.m., while in an industrial zone it can be 7 a.m. [20, p. 17].

Violation of noise legislation is subject to serious sanctions. Interesting examples are given in a paper written by American lawyers specializing in civil disputes. They write that in case of continuous noise a citizen will develop the state of "constant irritation"; and if it happens, they have the right to apply to the court. The effect of noise on a citizen and their consequences represent the caused damage, which can include loss of sleep, irritation or the inability to conduct normal activities. In this case, a citizen can apply for compensation for harm, indicating a reasonable amount for damage in dollars per day. The amount for which they can file a claim in court is limited from $\$ 2,500$ to $\$ 10,000$. For example, disturbances from noise for the period of 20 days give the opportunity to file a claim for compensation of $\$ 20$ per day, and this is usually considered to be a reasonable amount within the limit. If after the court decision on compensation for harm, the noise continues, it is possible to sue one more claim. In addition, if the interests of other neighbors are affected, then a group claim can be filed. If ten people sue for $\$ 2,500$, the total amount is $\$ 25,000$. Moreover, such a claim can be repeated and this will cost another $\$ 25,000$. Sooner or later, the noise should be stopped [20, p. 21].

American law knows a great number of examples of neighbor disputes. There are also a number of publications on neighbors' rights in the scientific doctrine. Law of neighbors in American law is closely related to other categories of property rights, in particular with easements and mortgages.

Recently there has been noted a doctrinal interest in the problems of neighboring relations settlement $[22 ; 23 ; 28 ; 30 ; 32 ; 33]$. A lot of attention is 
drawn to new concepts regarding the further development of neighbor law development in American law. In particular, it is proposed to regulate disputes on the basis of the actually existing model of neighborly relations. Firstly, there is a "stranger model", defined by the author as "a neighbor being a stranger", and a "friend model", where, according to the scientist, "a neighbor is a friend". With the help of these models, it is proposed to establish the peculiarities of the neighbor relations settlement. In case of the "neighbor-stranger" model, it is proposed to settle disputes by concluding agreements (contracts) regarding the use of neighboring land, as well as to settle the neighbors' disputes that have already arisen. At the same, it is possible to apply a "delictual" theory that offers protection to a neighbor by applying sanctions in case of unlawful intrusion of one neighbor into the possession of another one. Meanwhile, the American tradition proceeds from the fact that neighbors can agree to build a fence or plant a hedge, determine the line of the common boundary, and then register it together [32].

A landowner who has a tennis court in the yard can allow their neighbors to play there. In order to preserve the appearance of the building, a group of neighbors can agree to restrict activities connected with this building, for example, arrange a common landscape in the front yard, or consent to restrictions on the height and area of the building, on the placement of special signs. All these examples have a common ground, based on consent (agreement). Most of the legal relationships of neighbors are determined by extensive contract law, including many principles from the conclusion of a contract to the interpretation of its content and enforcement. The "neighbor-stranger" model is dominant in the regulation of neighboring legal relations in American law.

The US law also contains rules that establish the special rights and duties of neighbors with regard to the "neighbor-friend" model. It is believed that this model assumes friendly, intimate, family relations, so the rule of tolerance must act within it. The "neighbor-friend" concept is applied to cases where the mutual interests of neighbors can focus on support for local institutions, such as schools, churches, community groups and sports clubs, and joint participation in activities related to these mutual interests.

For such cases, there is a presumption of neighborliness. For example, in the context of neighborhood, a property owner may care less about excluding the right of a neighbor to enter their territory. In this interpretation, in the event of disputes on the protection of property from the neighbor's activities, courts solve them based on whether a neighbor acted intentionally to harm, whether there was hostility in their actions [32].

Concerning the legislation of some European countries and the United States, we can conclude that, despite the fairly old (Roman) origin of neighbor law, due to its natural-right status and its focus on the formation of a fair, balanced regulation of neighbors' rights of legally equal owners of real estate, this institution fully fulfills the tasks assigned to it today.

\section{Legal Model of the Neighbor Law Regulation in the Draft Civil Code of the Russian Empire}

Unlike European states, the law of prerevolutionary Russian did not have a separate system of rules governing legal relations between neighbors. V. I. Kurdinovsky wrote the following about neighbor law: "Until now, it is only in germ, and only contains several provisions that were established mainly in the $17^{\text {th }}$ century" [12]. He saw the reasons for this phenomenon "in the absence of the conditions analogous to those under which neighbor law developed in Western Europe in our country in the period preceding drafting of the Code". Undoubtedly, Roman law influenced the situation in Europe. Neighbors' relations in German states, and even in France are regulated by the rules that developed under the influence of Roman law. Roman law was unknown in Old Rus', and all the legal definitions had to be developed here from the very beginning. In addition, the development of urban life and the generally high population density in the countries of Western Europe promoted the development of neighbor law. There were no such conditions in Old Rus'. The size of the Russian state was immense. The population of many localities was insignificant. It took the property right centuries to reach the completeness we can see in the Code. The boundaries of individual landed estate have not been determined in some places up to this day [12, pp. 229-246].

The introduction of "neighbor law" in Russia was performed in the late $19^{\text {th }}-$ early $20^{\text {th }}$ century. However, an independent institution of neighbors' rights has never been formed. The institution of private participation right of the Civil Code unreasonably identified easements and rights of participation in the interests of neighbors. 
The formation of an independent institute of neighbor law was suggested in the Draft Civil Code of the Russian Empire (hereinafter referred to as the draft Code) [4]. The draft Code (1902) contained Chapter Three (Restrictions on the property right to the benefit of neighbors) of Book Three (Patrimonial right) (art. 49-74) devoted to neighbor law. Although the draft took the general concept of neighbor law that existed in the European legal system at that time, it can be argued that the provisions of the mentioned chapter differed both in the system of the neighbor law norms arrangement and in the basic principle in regulation of neighbors' rights.

To be precise, the project did not directly fix the rule established in $\S 906$ of the German Civil Code on the permissible impact coming from the neighboring land owner. It provided a general rule on the content of the "neighbor's right" of the real estate owner (art. 74), including the rule that if, when resolving disputes arising out of relations between neighbors by the court, there is doubt in the sense of the law and local regulations, there should be coordinated the needs and benefits of the estates, as well as interests of agriculture and industry with due respect to the right of ownership. Meanwhile, the obligation to "tolerate certain actions of a neighbor" originated from certain rules of the draft Code. In particular, art. 49 of the draft established a rule according to which the owner of an underlying estate had to tolerate the flow of water from the overlying estate and did not have the right to construct structures that would prevent this flow or change its natural direction causing detriment to neighboring estates.

The system of rules in the draft was presented as follows: art. 49-59 were devoted to the regulation of neighbors' relations concerning the use of water sources (the right to attach to the opposite shore a construction to deliver water for a fee, etc.); art. 60 established the right to build scaffolds on the land of a neighbor for a fee (to repair a structure or for a construction); in the comments to the article it is stated that the right to access to a neighboring land for building a construction is not considered possible [4, p. 214]; provisions on the "necessary road" were embodied in art. 61-63 (there was a similar rule in art. 57 about the right to lay water supply through a neighbor's yard in the absence of any other possibility); art. 64 established a general rule, according to which the rights specified in art. 57-63 should be carried out with the least possible constraint of the encumbered estate owner, who, in their turn, had to allow their neighbor to carry out all the actions necessary for the neighbor to exercise their right; art. 65 contained the rules on the right to erect fences for the common expense of neighbors; art. 66 set the permission to construct buildings of stone or other solid refractory material on the boundary, as well as prohibitions to make a roof slope, build drain pipes, sweep up the rubbish and drain dirty water or other liquids to a neighbor's land; art. 67 contained the rule that if a neighbor unintentionally put structures on a part of the neighbor's land, then if the owner of the land did not immediately object, the developer acquired the right of ownership to the developed neighboring land with the obligation to pay to the neighbor the value of the land that it had at the beginning of the construction works and pay the losses caused to the neighbor; art. 68 was devoted to the location of the stables, cesspools, sewage at the distance enough not to harm the neighbor. At the same time, the article establishes that the rules of the Construction Charter and local regulations must be observed; art. 70 recognizes the trees on the boundary as common unless otherwise is provided in the acts; art. 71 is devoted to the right to prune roots and branches penetrating from a neighboring land and to collect fruit that fell from the neighbor's tree hanging over the land; art. 72 sets rules on the windows made in the direction of neighbors' land (only with iron bars and blind frames, at the distance of three and a half arshins from the ground).

We do not find it possible to agree with the opinion expressed in the Russian legal literature that the study of "neighbor law" under the draft Civil Code is currently impractical: "Analysis of the relevant provisions of the draft Civil Code does not appear to be practical partly because the mentioned draft was never adopted, but mostly because it adhered to the general concept of neighbor law laid by the Code and thereby the tendency characteristic of its rules to lose the Russian national character. In terms of the ontological fundamentals of neighbor law in Russia, such an analysis will not give anything new" [3, pp. 52-53].

The analysis of the draft Civil Code of the Russian Empire allows us to talk about the attempt of its drafters to combine in it the national legal regulations well-known in the Russian judicial practice and the known provisions of the progressive 
Western legislations. It should be noted that a number of provisions originate from the Roman law (on the right to prune roots and branches of trees), there is similarity of some norms to the provisions of German neighbor law (on the right to the necessary road, construction works a neighbor's land), and French law (the right concerning windows facing a neighbor's land). However, it is possible to list the provisions of the draft Civil Code on neighbor law arising from the national needs that were relevant at the time. In particular, most of the rules of the neighbor law are devoted to restrictions in connection with the use of water sources (art. 49-59), which, in our view, is explained by the special geographical location of the Russian Empire. A large number of rivers, lakes and other water sources located on the Russian theory required the regulation of relations between the owners of estates that were situated near the waters for the economic use of water and shoreland. It should also be noted that the system of arrangement of rules in the draft Code had no analogues among the statutory acts governing neighbor law at that time. It does not have a clear division into general and special rules, there are no standards on the resolution of non-material impact from the neighboring land. Basically, the norms are grouped according to the subject of regulation (relations concerning the use of water sources, use of neighboring lands, structures located on those lands, trees and bushes growing on them); there is no division into material and nonmaterial impact.

Thus, despite the lack of legal recognition of neighbor law, the draft Civil Code of the Russian Empire established certain legal traditions of developing rules on neighbor law, which should be taken into account when developing the new Russian legislation. In particular, the provisions on the necessary road are of considerable interest. Further in the article, we will analyze this institution, as well as construction works on the neighbor's land, the possibility of introducing monetary compensation for certain actions of a neighbor on another person's land.

\section{Legal Model of Neighbor Law Proposed for Introduction into the Civil Legislation of Russia}

Russian law, as it was mentioned above, does not have a modern institution of neighbor law to- day. There are only separate rules in different legal acts which mainly contain public law restrictions on property rights.

The formation of neighbor law is provided by the draft law of the Russian Federation "On Amending Parts One, Two, Three, and Four of the Civil Code of the Russian Federation and Certain Legislative Acts of the Russian Federation" (hereinafter refered to as the Draft Law). Art. 293 of the Draft Law, entitled "Restrictions on the Land Ownership in Favor of Neighbors (Neighbors' Rights)", defines the notion of the admissible impact from a neighboring land, and lists its types. The analyzed norm seems to include the provisions of neighbor law that are in demand in current national practice. Nevertheless, in our opinion, the draft does not provide a full-fledged regulation of neighbors' relations, and unlike foreign codes, the tendency to prevent neighbor disputes is not very obvious. In particular, the draft does not contain provisions on the resolution of disputes arising when determining the boundaries, on the rule on the "necessary road", on buildings constructed in a neighboring land (in our code, it is called "unauthorized construction" and is regulated not by the provisions of neighbor law, but by provisions concerning the acquisition of title), the draft does not contain provisions on payment of compensation in case of the permission of impact from the neighbor, etc.

According to art. 293 of the draft law, the owner of the land must tolerate the impact of gases, vapors, smells, smoke, soot, heat, noise, vibration, etc. coming from the neighboring land, if it does not influence the use of their own land or the influence does not exceed the established standards, reasonable limits based on the natural features and location of the land or on custom.

In the case when the impact coming from the neighboring land exeeds the limits, the owner of the land has the right to demand removal of the inconveniences in the use of their land (art. 230).

Thus, in the content of the neighbor law notion, we can the idea of "tolerating an impact", which is traditional for the European legislation.

The Draft Law procedes from the existence of three types of impact coming from a neighboring land, followed by the relevant legal consequences: 
a) if it does not affect the neighboring land;

b) if it influences the use of the neighboring land in a way that does not exceed the established standards, reasonable limits based on the natural features and location of the land or on custom;

c) if it influences the use of the land in the way that exceeds the established standards, reasonable limits based on the natural features and location of the land or on custom.

The first two types of impact do not provide the right to a negator lawsuit, whereas the third type gives the right to demand removal of the inconveniences in the use of the land, i.e. the right to a negator lawsuit (art. 230).

It is possible to designate a criterion that gives grounds for filing a negator claim. It includes actions of the neighbor that exceed the limits of admissible impact.

In addition, it can be noted that part 2 art. 294 of the draft Civil Code (Content of neighbors' rights) includes: firstly, bans on certain actions of the owner in the interests of the neighbor; secondly, duties of the owner to implement actions at their site in the interest of neighbors. According to cl. 1 art. 294 of the draft law, unless otherwise provided by an agreement with the owner of the neighboring land, the owner of the land is obliged:

- not to erect buildings or structures in respect of which it is obvious that their existence or use will provide unacceptable impact on the neighboring land;

- to take measures to prevent harm that may be caused to the neighboring land by a building (structure) that is improperly maintained by the owner, including demolition of the building (structure) that has an admissible effect on the neighboring land;

- to eliminate the danger of the collapse of a building or a structure or its part to a neighboring land;

- to allow the owner of a neighboring land to access the land for digging and other works in order to access a building or structure located on the neighboring land, if it is necessary in order to repair it, if such works cannot be done in any other way;

- to pass freely water coming naturally to the land from a neighboring land, and also not to add soil on their land if it violates the natural run-off from the neighboring land or hampers it;
- not to construct buildings and structures on their land and not to plant anything in such a way that it can worsen the condition of a neighboring land or plants on it or disrupt the stability of buildings or structures located on it;

- not to deepen their land in such a way that the soil of a neighboring land will lose its support;

- not to construct wells in such a way that it prevents water from entering the well in the neighboring land;

- not to construct sewerage systems that lead to pollution of a neighboring land;

- to refrain from other actions that could lead to violation of the neighbors' rights.

In the last part of art. 292, on the contrary, there is a list of possible rights of the neighbor which constitute the admissible impact. According to cl. 2 art. 294 of the Civil Code of the Russian Federation, unless otherwise provided by an agreement with the owner of the neighboring land, the owner of the land has the right:

- to collect fruit that fell on the land from a tree or a bush located on a neighboring land;

- to prune and keep the roots of a tree or a bush that penetrating from a neighboring land that prevent the use of the land;

- to demand from the owner of a neighboring land not to do anything that can change the inflow of light to the land and not to narrow the view that opens from it, if it exceeds reasonable limits;

- to require the owner of a neighboring land to participate in the construction or bear reasonable expenses for the construction of a common wall (fence, hedge) between land lots or participate in the establishment of another dividing line between the lands (landmarks on common boundaries), as well as bear reasonable expenses for the operation of such facilities.

Thus, formulating the latter provisions, the legislator used a legal technique according to which they defined the content of the term "impact" as a set of possible rights of the owner in relation to a neighboring land.

In this regard, we believe that the judgments from the doctrine stating that the content of the Draft Law unreasonably established the compulsion of the owner to perform a certain action in favor 
of another person (in other words, the owner's obligation to perform certain actions) [3, pp. 77-78]. It should be mentioned that neighbors' rights include a complex of mutual legal relations, and that the right generates a counter obligation to perform an act or vice versa establishes a ban on the performance of an action.

In the literature, there is a number of critical remarks concerning the draft. For example, T. V. Krasnova believes that there are two rights wrongfully identified: the right of access for the owner of a neighboring plot for excavation and other works in order to access a building or a structure located on a neighboring land if it is necessary to repair it and if such works cannot be carried out in any other way, on the one hand, and easement, established by art. 301.7 of the draft Civil Code of the Russian Federation (easement for landworks to access the underground part of a building or a structure that is the main property during the construction, major overhaul and reconstruction of the building or structure) [10, pp. 44-45]. There are a number of critical comments on the Draft Law from representatives of the science of environmental law $[2 ; 13]$. For example, they state that the rules provided for in the draft are in contradicrion with the legislation on environmental protection. However, it will be shown further in the paper that actually the Draft Law contains provisions according to which the exercise of property rights should not violate environmental laws (for more details see the next section of the paper).

\section{Correlation of the Public and Private Methods for Legal Regulation of Neighbors' Rights: a Decision in Favor of the Civilian Concept}

Discussing the possibility of introducing restrictions on property rights in the interests of neighbors (neighbor law) into Russian law, it is necessary to analyze not only the essence and content of this institution, but also the legal nature of the rules contained in the mechanism of legal regulation. This refers to the branch-wise nature of the rules of neighbor law, as well as to the degree of discretion in exercising neighbors' rights. This issue is also currently relevant since in literature there is an opinion that neighbor law should mainly consist of the rules of public branches of law: land, environmental, urban planning, etc., whereas civil law can only form a minor sphere of legal regula- tion of relations between neighbors regarding determining the use of the neighboring boundaries.

In particular, O. I. Krassov, a scientist in the sphere of environmental law, states that the analysis of the legal norms on neighbor relations shows that these norms are the norms of environmental legislation and legislation on sanitary and epidemiological welfare of the population, which regulate the issues of negative environmental impacts (noise, vibration, air pollution, etc.), townplanning, land legislation, regulating the use of land, etc. There are norms of various branches of legislation in effect, but administrative and legal methods of regulation are applied more often. According to the scientist, a similar situation has been developed in foreign law [11].

In Krassov's oppinion, civil law scientists behave not "in a neighborly way" with regard to land and environmental law. Implementing their ideas in the draft Civil Code of the Russian Federation, they are trying to break into someone else's property, violate its boundaries, i. e. to trespass. The regulation of these issues by the Civil Code of the Russian Federation means an unjustified invasion of civil law in the spheres of legal regulation that are alien to it [11].

A similar opinion is shared by M. V. Bocharov, who believes that the content, design and list of restrictions in art. 293-295 of the Civil Code of the Russian Federation in the draft do not comply with the rules established by land, environmental and town-planning legislation, and introduce a parallel way to determine the legal regime of a land, which differs from the public procedure for the settlement of this issue [2].

S. V. Markin has similar views. He notes that in case of adoption of the draft Civil Code of the Russian Federation, appearance of these rights and duties of the land owner, which have not previously existed either in land or in civil legislation, will raise many questions in law enforcement practice [13].

It is interesting to note that the existence of public law regulation of neighbor relations allowed some authors to distinguish "public neighbor law" as an independent section of legal regulation [9].

In this regard, the correlation of public and private law in the protection of neighbors' rights is of particular interest. The public law legislation contains standards, town-planning norms and rules, 
sanitary epidemiological standards, which in their turn act as a measure for determining the significant impact on the land from the side of the neighbor. If legal limits and norms are violated, it testifies to the fact of unacceptable impact.

It should also be noted that the refusal of private law regulation of neighbor relations in our country was argued by Soviet lawers. In particular, I. L. Braude reasonably asserted that the basis for regulating neighbor relations in a socialist state is formed by administrative acts, and the main method of regulation is administrative and legal one, and therefore there are no sufficient grounds for formation of a special civil law institution of "neighbor law" [6, p. 100].

In the absence of private property and the dominance of administrative management in many spheres of society, it was unnecessary to form a private law institute for the right of neighborhood. Moreover, the presumption of compensatory relations between neighbors when one of them exceeded the limits of the admissible impact, as well as the very possibility of concluding agreements between private individuals regarding the land use contradicted the essence of the socialist state property. All these made establishing easements impossible at that time.

The branches of public law establish the boundaries for the exercise of property rights, including through special rules (fire safety, town-planning, sanitary, epidemiological, environmental, etc.), but as I. B. Novitsky says "no amicable agreements" have legal value in public law [6, p. 100].

It is the civil law that regulates neighbors' rights from in terms of discretion, provides an opportunity to regulate private relations between neighbors by concluding agreements, and establishes provisions aimed at preventing neighbor disputes.

It should be noted that in the developed foreign legal order, where the institution of neighbor law has been known for a long time (Austria, Germany, Switzerland, France), a special mechanism for regulating neighbors' rights has been created, which refers to civil law regulation. Accordingly, the rules on neighbor law are placed in civil codes of the mentioned countries. That is why foreign literature emphasizes the special private law nature of relations between neighbors. The idea of goodneighborly relations based on a limited neighbor's impact on another person's land within private law regulation was put forth in the Middle Ages. In Roman law, the fundamental theory was the absolute property doctrine, and it was believed that a neighbor could do various things on their land at their own discretion. In the Middle Ages, pandecticism developed provisions according to which it is impossible to establish good-neighborly relations if a neighbor does not tolerate their neighbor's actions on their neighbor's land within certain limits (the theory of "ordinary tolerance" (Jhering).

Otherwise, the life of neighbors would turn into a series of endless claims to each other, disputes and litigation. The idea of neighbor law is based on the concept of mutual assistance of neighbors in the exercise of their rights, on the prevention of disputes, and protection of their rights in courts in the case of violations. In this connection, O. F. Gierke wrote that neighbors' rights are "pure" private rights, so an authorized person can refuse to exercise their rights [6, p. 100].

Unlike civil legislation, the rules of the legislation on environmental protection and the law on sanitary and epidemiological welfare of the population prohibit the negative impact on the environment, affecting and including the sphere of regulation of neighbor relations in case of compensating for harm to the natural environment.

For comparison, let us note that in foreign law for regulation of private law disputes of neighbors, norms of environmental legislation are applied subsidiarily to the norms of civil law as the criteria to determine whether the neighbor's actions go beyond the limit of the admissible impact. Norms of public law taken independently do not contribute to the resolution of neighbor disputes, including compensation for harm caused to the health of citizens being neighbors and to their property.

The inconsistency of the Russian legal doctrine is shown by the very last circumstance on the necessity to apply norms of public law to neighbor relations in order to determine whether the neighbor's actions are within the admissible limit. O. I. Krassov states: "A number of these "neighbor's" rights, for example, the right of the land owner to prune and keep the roots of a tree or a bush 
that have penetrated from a neighboring land to their land, contradicts the right of every person to a favorable environment enshrined in art. 42 of the RF Constitution. Such an operation is likely to lead to the death of the tree. Are the developers of the draft not sorry for a century-old oak or a huge pine, which they doomed to perish?" [11].

He also believes that the Draft Civil Code contradicts the norms of environmental law, which in certain cases provides for the protection of plants and prohibits their destruction, if a tree, for example, is declared to be a natural feature and the owner of the land on which it is located assumed obligations to ensure the regime of special protection for the feature, when the tree grows on a private land located in the national park included in the protected area, for example, wildlife preservation, or another specially protected territory [11].

However, the author of these assumptions overlooked a very significant rule (cl. 2 art. 286) that follows from the draft law, according to which "the owner exercises their rights to the land in accordance with its designated purpose and permitted use and with observance of environmental requirements".

Nowadays, cl. 3 art. 209 of the Civil Code states that ownership, use and disposal of land and other natural resources to the extent permitted by law is exercised by their owner freely, if this does not damage the environment and does not violate the rights and legitimate interests of other people. Thus, the rules on property rights restrictions in the interests of the neighbor are subject to general provisions on the right of ownership and, accordingly, if there are mandatory rules established by the law on environmental protection, a neighbor must comply with certain prohibitions. Therefore, the Civil Code protects trees and plants included into the Red List, and the norms of the Civil Code of the Russian Federation contain grounds for prohibiting destruction of a century-old oak, if such action contradicts the right of a person to a favorable environment.

In the acts of public legislation of Russian law, one of the most common measures established by the state with respect to organizations polluting the environment is a fee for the negative impact on the environment, embodied in art. 16 of the Federal
Law of January 10, 2002 No. 7 "On Environmental Protection". This fee is to be credited to the the budget of the Russian Federation. In addition, the Law on Environmental Protection establishes criminal and administrative liability, fees for environmental pollution, compensation for harm to the state, as well as that caused to private individuals as a result of economic and other activities of legal entities and individuals.

In this regard, we should agree with O. Bogatyrev, who, distinguishing between public and private norms on neighbor law, notes the following: firstly, the violation by an owner of a public law rule does not give their neighbor the right to sue against the offender - in this case, interference is only possible from the competent authorities; secondly, as a rule, norms of neighbor law are of a discretionary nature and can be canceled or amended by an agreement between the owner and their neighbor, which cannot be done with respect to public law restrictions [15].

\section{Theoretical and Legal Model for Contractual Regulation of Neighbor Legal Relations}

As it was mentioned above, restrictions on property rights in the interest of neighbors arise on the basis of the law. Meanwhile, modern legislation systems provide the possibility of contractual regulation of relations between neighbors as an exception. A similar rule is provided for by the draft law on the amendments to the Civil Code of the Russian Federation. In particular, cl. 1 art. 294 of the draft Civil Code (The content of neighbors' rights) establishes prohibitions and obligations for the owner to perform certain actions on their land in the interest of neighbors, unless otherwise provided by agreement. Thus, cl. 1 art. 294 of the draft law establishes a discretionary rule along with mandatory rules. According to this rule, the landowner is obliged to observe restrictions on the right of ownership in the interests of a neighbor unless otherwise provided for by an agreement with the neighboring land owner. However, it should be noted that in the national literature there is still no research that might bring at least some clarity about the nature of this agreement, its content, the principles of legal regulation, the grounds for conclusion, and the scope of application. 
The possibility to settle a neighbor relationship by means of an agreement or a contract is also established in foreign law. For example, according to par. $2 \S 906$ of the BGB, if the owner has allowed an impact on their land, they have the right to demand from the user of the other land an equivalent monetary compensation, in the event this impact violates the customary use of their land or prevents to obtain income from the land more than it is permitted by the law.

Establishment of easement that eliminates prohibitions determined by law is deemed possible in the literature. In particular, T. S. Krasnova admits the possibility of cases when neighbors conclude an agreement on another procedure for the neighbors' rights implementation, as a result of which one neighbor obtains the right to limited use of the other neighbor's real estate; this right can be qualified as easement if it meets all the essential attributes of easement, including the objective need for its establishment. Another solution is possible after the "voluntary easement" category is introduced into Russian law [10, p. 45].

A number of questions arise in this connection, which do not have unambiguous answers in the civil law literature. For example: what is the significance of the given agreement? is it possible to apply provisions on obligations, including the rules on freedom of contract?

The possibility of contractual definition of neighbors' rights proceeding beyond the statutory restrictions on property rights has existed for a long time, and it was known to the Russian prerevolutionary law.

For example, another Russian civil law scholar V. B. Elyashevich considered easements established by means of an agreement (the right to remove sewage through the neighbor's yard despite a legal restriction) among the elements of neighbor law. He supposes that in this way the owner "discards the restriction lying on him and thereby widens the sphere of his legal domination, and acquires a right that he has not had by law" [5].

G. F. Shershenevich deemed it possible when an agreement between neighbors eliminates the prohibition to design windows and doors facing a neighboring yard established by law. In this case, the neighbors establish easement [19, p. 176].

Analyzing the nature of the agreement that eliminates the restriction on property rights in the interest of the neighbor, it seems that in this case it should concern establishment of a new limited real property right of an easement type that is a subject to the rules of property law. At the same time, it should be remembered that the content of a corporeal legal relationship follows from the law, and not from a contract.

Thus, such an agreement is only possible in the case of establishing easement and by means of the legal regulation of the property law rules. The legal regime of the parties' actions at the conclusion of an agreement must be regulated by the Numerus Clausus (i. e. rules of the closed list of grounds for the establishment of easement and its types by the law).

It should be reminded that above in this article there has been considered a model of contractual regulation of relations between owners under American law. However, the proposed model of introducing a private agreement differs significantly from the American one, which is based on the freedom of contract and on the possibility of discretionary regulation of the owners' relations when establishing the neighbors' rights.

This article proposes the possibility of concluding a private agreement between neighbors in order to change the property rights restrictions established by law in the interests of the neighbor, but on the condition that such an agreement is only possible within the easement and is based on the fundamental property law principle Numerus Clausus.

\section{Theoretical Problems \\ of Differentiating between Easements and Neighbors' Rights: on the Nature of the Right to the "Necessary Road"}

The grounds for the differentiation between easements and neighbors' rights have long been developing in the civil law literature, and they seem not to cause serious disputes in the law enforcement practice. However, the national law requires solution of certain aspects of relations between neighbors in connection with the development of the draft on neighbor law [7]. The question is about the possibility of establishing a legal institution similar to the German "necessary road". In the German Civil Code, the right to the "necessary road" is regulated within the system of neighbors' rights as the right of passage to one's own land (in exceptional cases) enshrined in law. Accordingly, it establishes restrictions on the property rights of the owner in the interest of the neighbor who does not have access to their home. Russian law does not know such a restriction on property rights, and similar situations are proposed to be resolved by establishing easement. Meanwhile, German law clearly differentiates between the right of passage as a restriction 
on property rights and easement of the passage. This issue is quite interesting for Russian civil law, as today there are active discussions about the establisment of a right of way as an independent category.

V. I. Kurdinovsky clearly outlined the criteria for differentiation of these easements. He wrote: "Restrictions with such content are very similar to easements (pati, non facere) and were called legal easements before. However, time passed and it became clear that these restrictions differ from easements, and the term "legal easements" was not used amymore to identify property rights restrictions. According to the lawyers, the difference between legal restrictions and easements is that under easements the limitation of the owner's power is a consequence (the reverse side) of the other's private right, while the restriction of the law is itself the source of the right for a third person; it is 'das Principale', the right of a third person is 'das Secundare'. Then, the legal restriction on the right of ownership occuring at the moment when it arises deprives the owner of certain powers in advance (von vornherein). Easement limitates the already existing property right, restricts the owner after a certain time, hinterher. In addition, easements exist because of the individual needs of a particular person or thing; they determine the scope of right; easement loses its force after the needs disappear; it means that easement is of conditional and temporary nature. Legal restrictions on the right of ownership do not depend on the individuality of the person or thing; they are established in the interests of everyone who is in a certain (equal with others) situation, and continue to exist until their abolition by law, not until the disappearance of a particular need" [12, pp. 229-246].

A land owner's right to the "necessary road" in the event of a need in such a road is unknown to Russian civil law in the form of an independent legal institution. Due to the lack of legal norms on the property right restriction in the interest of the neighbor (neighbor law), it is quite obvious that such a right cannot be qualified as a special restriction. Meanwhile, in modern Russian, the situations are quite common when a natural need arises to lay a pedestrian road or a transport pas- sage to the public road through a neighboring land.

Russian law provides for two options for legal regulation of this owner's need: by establishment of a so-called land public easement or private easement. Public easement is established by law or another regulatory legal act of the Russian Federation, its subject, or the local government in cases when it is necessary to ensure the interests of the state, local government or local population, without exemption of the land. The Land Code of the Russian Federation regulates 9 types of public easements, including that for passage through a land, for ensuring free access of citizens to a public water body and its shoreland, for usage of a land in order to perform utility repair, engineering, electrical and other works and transportation facilities.

Private easement is regulated by cl. 1 art. 274 of the Russian Federation Civil Code. According to it, an owner of immovable property (land or other kinds of real estate) is entitled to demand a right of the limited use in regard of the neighboring land (easement) from the neighboring land owner, and when it is necessary - from another land owner (neighboring land).

It can be stated that in the Russian legislation the right to the necessary road has acquired the legal construction of easement (public or private).

Such qualification of the right to the necessary road goes against the dogmatic construction of this institution as a proprietary right. It contradicts the legislation as well as law enforcement practice in the countries of continental Europe, where private law has the greatest similarity and closeness to that of Russia. The fact is that developed foreign legal systems, making the private property right one of the most important constitutional rights, have justified the dominance of the interests of the land owner in the case when they are deprived of the right to access their land for reasons beyond their control over the interests of the owners of the neighboring land where it is necessary to provide the access. The law of Germany, Austria, Switzerland, France, Latvia, Georgia, Tajikistan, etc. considers the right to the necessary road solely to be a restriction on property rights in the interest of the neighbor, for the establishment of which there is no need to conclude 
a special agreement on easement and which does not require special registration.

Thus, according to the logic of the legislator in these countries, interests of the private owner who is deprived of the natural right to own and use their land for lack of access to it, through no fault of their own, are much more restricted than the interests of neighbors who are forced not to prohibit the right of way through their territory, exercising the responsibility to tolerate the actions of their neighbor when passing for a fee. The least encumbrance of the neighbor's right, absolute lack of access to the land, the obligation to pay before exercising the right are recognized as mandatory conditions for the right of way.

The draft Civil Code of the Russian Empire also considered the right of the necessary road to be the form of restriction on the right of ownership. According to art. 61 of the draft Civil Code, if an estate surrounded by neighboring lands from all sides has no access to the public road, then the estate owner has a right to demand that their neighbors allocate land for the road necessary for access to the estate and its economic use, which is to be done for appropriate compensation. The following is stated in the Explanations to the draft Civil Code of the Russian Empire on the right of the necessary road, established in art. 61 of the Code: "The rules of this article are based not only on the natural sense of justice, but also on the interests of public law. In fact, the state is interested in ensuring that no part of the land is left without cultivation, since the welfare of private farms is only a component, and the total amount of these components is the welfare of the state. That is why the law should authorize the owner of a property isolated from all its sides to demand from neighbors allocation of land for the road necessary for access to the estate and its economic use" [4, p. 215].

Thus, the modern Russian law considers the right to the necessary road in two legal constructions: public and private easement.

Obviously, the former does not contribute to the protection of the private person's interests on the passage through the neighbor's land, because it only serves the public and its interests. The latter requires conclusion of an agreement with the neighboring land owner to meet the need for passage, and, as the Russian practice shows, in many cases a neighbor does not sign the contract voluntarily. In this connection, the situation typical of Russia is when the establishment of easement de- pends on a court, where such a claim can be denied for formal reasons. Obviously, the land owner is deprived of their right of access to their land as long as the court proceeding on the easement establishment lasts, and that is definitely a violation of their natural right to private property. Such a ban on the owner's right to access their land, and often the house (dwelling), can hardly be called appropriate in accordance with the Constitution of the Russian Federation, which guarantees the implementation of the most important constitutional right to private property.

At the same time, a peculiar right of passage is embodied in cl. 2 art. 262 of the Civil Code of the Russian Federation: "If the land plot is not fenced or its owner has not clearly indicated by other means that the entrance to the land without their permission is not allowed, any person can pass through the land on condition that it does not cause damage or concern to the owner, if there is no prohibition to go through the neighbor's land without the permission of the landowner, and, accordingly, the prohibition of the right of the necessary road". However, in this situation, we are talking about presumption of the right to passage through the neighbor's land when there is no explicit prohibition.

The right to the necessary road as a property rights restriction is possible in cases when a neighbor, as a party of an absolute legal relationship, does not allow all third parties to pass through their land. The right of passage will be possessed only by the owner of the adjacent land, and only in a situation when they are completely of the possibility to access their own land.

In the countries of the continental law, the right of passage through neighbor's land is possible, both within the property rights restriction in the interests of the neighbor (in exceptional cases where access is not available at all) or by establishment of private easement as the right to access their land. But, unlike Russian law, private easement of passage is established by agreement, or because it has been historically applied. As a rule, establishment of easement against the will of the owner is impossible, and there is a special property rights restriction in the interests of the neighbor. In case of violation of the owner's right to the necessary road (i. e., there is no possibility for a legitimate passage at all, and the neighbor interferes with the implementation of the right of access to the land and dwelling), they can apply to the court with a negative claim to remove obstacles in the 
right of way (not with a claim for the establishment of easement).

It seems that there have been quite objective reasons for the formation of the private person's right to passage as private easement, not as a property rights restriction of the neighbor's interests in the Civil Code of the Russian Federation (1994). It was impossible to secure the neighbor's right to free access to their land in case of lack of access to the land in the country where there was no fullfledged right to private ownership of land at that time (as it is known, Chapter 17 of the Civil Code of the Russian Federation on the ownership of land was frozen until 2001).

Thus, ignoring private interest as the basic value of a man, extermination of the normal principles of private property from the minds of our society during the $20^{\text {th }}$ century, all these lead to the result when the society negatively perceives a legislatively established opportunity for the owner to pass through the neighbor's land in case there are no any other ways to access the land. Obviously, in this situation it is necessary to take into account the balance of interests of both owners: that of the owner whose land will be used for passage, and that of the other - who is deprived of the possibility to enter their property. It is clear enough that in this situation, the inability to use the land, building and other objects which are in property is a greater violation of human rights than the establishment of an obligation to tolerate the right of a neighbor to pass through a private land for a monetary reward. The prohibition of passage in such a situation is not only unfair but also testifies to the lack of proper respect for private property and for the individual's dignity.

It should be noted that in Russian law there is no such restriction on property rights, it is supposed to regulate the relevant relations with the use of easements.

Today the absence of perfect legal regulation for relations on the right of passage to a certain extent serves as a basis for disputes about the establishment of easements.

Let us pay attention to the fact that according to the Review of Judicial Practice on the Establishment of Easement on a Land Plot (approved by the Presidium of the Supreme Court of the Russian Federation on April 26, 2017), the prevailing number of disputes arise from the need to establish a right of passage to a public road, a right of access to communications for their repair and exploitation.

The need for the use of neighboring land for passage is a really topical issue nowadays. This is due to the latest events in our country connected with redistribution of public land ownership during privatization, mass construction of cottage settlements, changes in urban and rural infrastructure because of various well-known events (Sochi Olympics, the upcoming Football World Cup, etc., construction of the federal highway "Tauris" and Crimea energy supply, etc.), changes in legislation on the dacha, gardening and gardeners' associations for the use common property of such associations. Judicial practice also testifies to the tendency. For example, there was a case considered by the Constitutional Court of the Russian Federation when the "Barvikha" dacha community association sold the land of common use to a private person who started construction works. As a result, the members of the association, and in particular the owners of the dachas, were deprived not only of the right to use the common infrastructure, but also of the land occupied by roads. Proposals for the application to such development of a regime similar to the common shared property of an apartment building tenants did not receive support from the Constitutional Court of the Russian Federation [1]. At the same time, the Council for the codification of civil legislation criticized the model for regulating property relations of dacha communities proposed by a bill on changing the law "On horticultural, gardening and dacha non-profit associations of citizens". The draft law suggested using a model when the common property (roads, communications, etc.) is owned by the association itself as a basic one. In the opinion of the Council, such regulation of public property of a dacha association would create difficult problems in the situation when one of the partnership members is expelled from the association (for example, for failure to pay contributions, etc.). As the representatives of the Council noted: "It turns out that in order to get to the land, the owner will have to negotiate about establishing easement and somehow gain access to communications" [1].

The issue on such property is still not completely settled, and, accordingly, there remains a gap in the regulation of the right of access to communications and access to the land by residents of 
dacha communities, i.e. the question of the "necessary road" also remains open.

It is necessary to pay attention to the fact that there is a vast court practice dealing with disputes when there is interfered right of workers to access enterprise, the right of neighbors to access the pedestrian road, the right of departure, etc.

The prohibition of the right to passage through someone's land to the owner's land in the absence of other access is a cruel rule, which refutes the right of private property, proclaimed by the Constitution of the Russian Federation as the highest value of a person.

It seems that the design of private easement known to our legislation does not defend the rights of owners mentioned in this article in a proper way since easement must be established by agreement. In most cases, neighbors have to go to court. Therefore, the category of a private law restriction on property rights of a neighbor in the form of granting access to the neighboring land is interesting as a potential legal model for settling legal relations between owners of adjacent lands (neighbors) in the event that any of them has no actual access to their private property (land or another real estate object).

\section{Conclusions}

The analysis of legislation, doctrine and judicial practice concerning restrictions on the right of ownership to private property in countries with different legal systems allows us to distinguish two legislative models of property rights restrictions in the interest of the neighbor (European and American).

The European model is based on the legislation of such countries as Germany, Austria, Switzerland, Finland, so they are Roman law principles of property rights restrictions that actually underlie it. The doctrinal treatment of restrictions was carried out with the development of doctrine in European countries, including works of pandect law, which played a large role.

The main features of the European model are as follows:

1) Division of the law into private and public has a clear differentiation between public law restrictions on the ownership right and private law ones. The first are established in acts of public law and have the following features: imperative content; cannot be changed by agreement of the parties; emergence by force of law; have the form of administrative or criminal prohibition (are punishable by administrative, criminal and civil law). In particular, they include town-planning norms and rules, norms of forestry, water, land legislation, norms on environmental protection, etc. As a rule, they are not regulated by the Civil Code, but are enshrined in separate laws. In case of regulating relations of landowners, they are used in conjunction with private regulators.

2) Private law restrictions on property rights are presented as restrictions on property rights in the interest of neighbors. The following characteristic features of theirs are noted:

a) they are based on the law, but may be amended by agreement of the parties in cases prescribed by law;

b) they are regulated by civil law (Civil Code of Germany, Common Austrian Civil Code, Civil Code of Switzerland);

c) they are aimed at the solution of the following tasks: protection of the neighbors' interests in case of violation of their rights; defense through a negative claim; not bringing the dispute to court by establishing norms that facilitate the resolution of the dispute;

d) the neighbor's right includes their right to impact (emission) on a neighboring land. At the same time, the basic principle here is tolerance, i. e. "to tolerate an impact that does not exceed the limits established by law, local rules, traditions, etc." The limits established by law follow from public law. Traditional limits mostly often proceed from the norms established in the corresponding community and are subsequently confirmed in court.

In addition, neighbor law contains norms of civil law, which include ways to settle a neighbor dispute at the pre-trial stage. These are the rules for settlement of disputes in case of unauthorized construction, determination of boundaries, use of the boundary line, the necessary road, adjacent fences and trees.

These private law provisions are aimed at protecting the private interest of a neighbor, contribute to the restoration of their private neighbor right without recourse to public authorities and public law acts. These include the provisions of $\S 907-923$ BGB on unauthorized construction works on the neighbor's land; on a threat of a structure's collapse; on determining a common boundary; on construction and maintenance of the boundary 
facilities and landmarks; on the right to the "necessary road".

3) There is a possibility of contractual settlement of a dispute, and the obligation, imposed by the will of the parties, to tolerate the impact beyond admissible in cases permitted by law for a fee specified in the agreement (to tolerate the impact from the neighbor for a fee).

4) In the case a neighbor exceeds the limits of the admissible effect, a negator lawsuit in neighbor law is applied, as well as general provisions on compensation for harm. And one more feature of the European model is a clear delineation between restrictions on property rights and limited proprietary rights. The latest legislation of the European legal order, as a rule, includes usufruct, easements, servitudes, real encumbrances, pledge, preferential rights.

The American model of regulating neighbor relations is characterized by the lack of not only a clear differeniation between public and private regulation in the real estate law, but also of an independent branch of private law as such. The states are given broad discretion in legal regulation, so the restrictions vary from state to state. In this connection, it is hardly possible to speak about the existence of property rights restrictions in the neighbor's interests in the U.S. law similar to the institution existing in German law.

Nevertheless, the American model knows neighbor law, which can be described as a set of rules of various regulations on the rights of neighbors, coming from the law on the zoning of territories, on the condominium, on the periods for noise-making, dog's barking, etc. Such public law regulation has a serious impact on the responsibility for violation of public rules, which varies in the laws of the states and entails both criminal penalties and fines.

The rules on neighbor relations used in the U.S. law classify neighbors' rights as rights of a neighbor to be protected against unreasonable noise, to construct fences, to determine boundaries, to use and maintain common trees.

In American law, there is a dominance of the private interest of the owner of land and other real estate and the protection of private property as an absolute right from any neighbor's actions. This distinguishes the American model from the European concept of tolerance, when in certain cases it requires to tolerate an impact. It can be assumed that the neighbor's behavior for protection against any, even minor, actions on the part of their neighbors is the basis for the emergence of a dispute between neighbors from a psychological perspective. Therefore, the US law implements an imperative order of regulation with increased public responsibility for violation of the property right (illegal intrusion, etc.) to settle disputes between neighbors. This order is accompanied by high penalties, criminal punishment, including deprivation of liberty in some cases, and all these contribute to the cessation of illegal activities and, accordingly, settlment of disputes between neighbors.

It is obvious that the European model of property rights restrictions is the most acceptable for both the law of Russia and other post-Soviet countries. This conclusion is supported by the fact that for centuries Russian law has been based on the division of the law into public and private, has adhered to the differentiation between the property right and limited proprietary rights; private law has been based on discretionary regulation. The prerevolutionary Draft Civil Code of the Russian Empire (late $19^{\text {th }}-$ early $20^{\text {th }}$ centuries) provided for the introduction of property rights restrictions, including neighbor law similar to the model of legislation developed in Germany, Austria, Switzerland and France. In addition, the protection of private interests is among the main principles of law in the civil law of Russia, Belarus, and Kazakhstan. The protection of property rights, including the neighbor's right, is provided by a negatory action, i. e. similar to the European model.

On the other hand, some elements of the American model of property right restrictions could be a subject of scientific analysis and discussion for the purpose of further borrowing. For example, the public law regulation of neighbor relations used in American law, including numerous acts of the local level, seems to be rather promising for us. Moreover, it should be noted that public regulation of relations between neighbors was dominant in Soviet law in the post-Soviet countries. However, when comparing private law and public law regulation, it is necessary to take as a basis the approach developed by the German legislator, in accordance with which the acts of public law have subsidiary regulation in comparison 
with the acts of civil legislation (used to determine whether a neighbor exceeds the limits of the admissible impact).

It seems possible to introduce the contractual regulation of relations between owners existing in the American model. However, the proposed model of introducing private agreement significantly differs from the American one, which is based on the freedom of contract and the possibility of discretionary regulation of the owner's relations when neighbors' rights are established. The present article assumes the possibility of concluding a private agreement between neighbors in order to change property rights restrictions specified by law in the interests of a neighbor, but on the condition that such an agreement is only possible as part of the establishment of easement and is based on Numerus Clausus (i.e. rules of the closed list of grounds for the establishment of easement and its types by the law). It is impossible to ignore the principles of mandatory responsibility (administrative and criminal) for illegal intrusion into the neighboring land. At the same time, it is necessary to strengthen in neighbor law the rules on the possibility of an agreement between neighbors to "tolerate" the neighbor's actions (for example, to allow for the necessary road) for monetary compensation or to establish the need to tolerate the insubstantial actions of a neighbor without compensation within the limits prescribed by law, as it is done in the European model.

Some of the ways to settle a dispute applied in American law are also interesting to study. In particular, considering development of the mediation institution in Russia, some elements from American law can be used to develop neighbor mediation in our country.

The provisions presented in this article, known to German law as a form of the property rights restriction in the interest of the neighbor - "the right to the necessary road", are of both theoretical and practical interest, and at the same time require further development. The draft Civil Code of the Russian Empire also considered the right to the necessary road as a restriction on the ownership right (art. 61 of the draft).

The article provides arguments that justify the need to address the category of private law restriction on the neighbor's property rights in the form of granting access to the neighboring land in the event that the neighboring owner does not have an actual access to their property.

\section{References}

1. Bagaev V. Obshchemu imushchestvu ishchut osobuyu sud'bu. Zakonoproekty o sadovodstve $i$ o prodazhe dolevoy sobstvennosti ne podderzhany Sovetom po kodifikatsii [They Seek a Special Destiny for Common Property. Bills on Gardening and Sale of Common Property are not Supported by the Council for Codification]. Available at: http:// zakon.ru (accessed 13.01.2017). (In Russ.).

2. Bocharov M.V. Proekt Grazhdanskogo kodeksa: oborot nedvizhimosti v opasnosti [Draft of the Civil Code: Real Estate Sales in Risk]. Yurist - Jurist. 2012. Issue 10. Pp. 21-28. (In Russ).

3. Vinichenko Yu. V., Aslanyan N. P., Porotikova.A. Sosedskoe pravo v Rossii: istoricheskie nachala $i$ podkhody $k$ ponimaniyu [Neighbor Law in Russia: Historical Origins and Approaches to Understanding]. Moscow, 2014. 152 p. (In Russ.).

4. Grazhdanskoe ulozhenie. Kniga tret'ya. Votchinnoe pravo. Proekt Vysochayshe utverzhdennoy Redaktsionnoy Komissii po sostavleniyu Grazhdanskogo Ulozheniya. S ob"yasneniyami [The Civil Code. The Third Book. Patrimonial Right. The Project of the Drafting Committee on Drafting the Civil Code by Imperial Consolidation. With Explanations]. St. Petersburg, 1902. 630 p. (In Russ.).

5. El'yashevich V. B. Pravo uchastiya chastnogo $i$ ego zashchita [The Right of Private to Participation and Its Defense]. Vestnik grazhdanskogo prava - Civil Law Review. 1914. Issue 2. Pp. 18-35. (In Russ.).

6. Emelkina I. A. Institut ogranicheniya prava sobstvennosti $v$ pol'zu sosedey (sosedskoe pravo) $v$ rossiyskom prave $i v$ prave otdel'nykh evropeyskikh stran [Restrictions of Ownership Title in Favor of Neighbors (Neighbors' Rights) in Russian Law and in Law of European Countries]. Vestnik grazhdanskogo prava - Civil Law Review. 2016. Issue 2. Pp. 79-112. (In Russ.).

7. Zhivov A. A. O sosedskom prave i predial'nykh servitutakh [Law of Neighboring Tenements and Easements]. Istoriya gosudarstva i pravaHistory of State and Law. 2012. Issue 2. Pp. 21-24. (In Russ.).

8. Kontseptsiya razvitiya grazhdanskogo zakonodatel'stva Rossiyskoy Federatsii, odobrena Sovetom po kodifikatsii grazhdanskogo zakono- 
datel'stva Rossiyskoy Federatsii pri Prezidente Rossiyskoy Federatsii 7 oktyabrya 2009 goda [The Concept of Development of Civil Legislation of the Russian Federation, Approved by the Council for Codification of Civil Legislation of the Russian Federation under the President of the Russian Federation on October 7, 2009]. Vestnik Vysshego Arbitrazhnogo Suda Rossiyskoy Federatsii - Herald of the Supreme Arbitrazh Court of the Russian Federation. 2009. Issue 11. Pp. 6-99. (In Russ.).

9. Korolev S. V. Ekologicheskiy imperativ sine qua non tsivilistiki XXI v. [Environmental Imperative Sine Qua Non of Civil Jurisprudence of the $21^{\text {st }}$ Century]. Ekologicheskoe pravoEnvironmental Law. 2010. Issue 2. Pp. 33-36. (In Russ.).

10. Krasnova T.S. Prinuditel'nost' $i$ avtonomiya voli $v$ servitutnom prave: dis. ... kand. yurid. nauk [Compulsoriness and Autonomy of Will in Servitude Law: Cand. jurid. sci. diss.]. St. Petersburg, 2017. 263 p. (In Russ.).

11. Krassov O. I. Pravo sobstvennosti na zemlyu v stranakh Evropy [Ownership of the Land in European Countries]. Moscow, 2014. 400 p. (In Russ.).

12. Kurdinovskiy V.I. K ucheniyu o legal'nykh ogranicheniyakh prava sobstvennosti na nedvizhimost' $v$ Rossii [To the Doctrine of Legal Restrictions on the Ownership of Real Estate in Russia]. Odessa, 1899. 396 p. (In Russ.).

13. Markin S. V. Sovershenstvovaniye pravovogo regulirovaniya prava sobstvennosti na zemel'nye uchastki [Development of Legal Regulation of the Property Right to the Ground Areas]. Pravovye voprosy nedvizhimosti - Legal Issues of Real Estate. 2012. Issue 2. Pp. 21-24. (In Russ.).

14. Nykänen P. Priobretenie zemli i stroitel'stvo $v$ Finlyandii [Purchase of Land and Constructing in Finland]. Transl. by I. Prilezhaev. St. Petersburg, 2009. 159 p. (In Russ.)

15. Pravo sobstvennosti: aktual'nye problemy; otv. red. V. N. Litovkin, E. A. Sukhanov, V. V. Chubarov [Ownership: Current Problems; ed. by V. N. Litovkin, E. A. Sukhanov, V. V. Chubarov]. Moscow, 2008. 731 p. (In Russ.).

16. Sukhanov E. A. Veshchnoe pravo. Nauchnopoznavatel'nyy ocherk [Property Law. Scientific and Educational Essay]. Moscow, 2017. 560 p. (In Russ.).

17. Chubarov V. V. Problemy pravovogo regulirovaniya nedvizhimosti [Problems of Legal
Regulation of Real Estate]. Moscow, 2006. 336 p. (In Russ.).

18. Khvostov V. M. Sistema rimskogo prava [System of Roman Law]. Moscow, 1996. 522 p. (In Russ).

19. Shershenevich G. F. Uchebnik grazhdanskogo prava [Textbook on Civil Law]. Moscow, 1995. 556 p. (In Russ).

20. Doskow E., Guillen L. Neighbor Law: Fences, Trees, Boundaries \& Noise. Berkerly, CA: Nolo Press, 2017. 355 p. (In Eng.).

21. Finck M., Ranchordás S. Sharing and the city. Available at: http:// SSRN-id2741575 (accessed 12.01.2018). (In Eng.).

22. Freyfogle E. T. Property rights, the market, and environmental change in twentieth-century America. Illinois Public Law and Legal Theory Research Papers. Series Research Paper. 2001. Issue 00-01. November. Available at: http://ssrn. com/abstract $=\mathrm{id} 907842$ (accessed 12.01.2018). (In Eng.).

23. Gierke O. Deutshes Privatrecht. Zweiter Band. Sachenrecht. Leipzig, 1905. 598 p. (In Germ.).

24. Iro G. Bürgerliches recht. B. IV. Sachenrecht. Dritte Auflage, Wien, New York, 2008. 270 p. (In Germ.).

25. Jordan C. Neighbor Law: Fences, Trees, Boundaries \& Noise. Berkeley, CA: Nolo Press, 1998. 352 p. (In Eng.).

26. Koziol H., Welser R. Grundriss des burgerlichen Rechts. B.1. Allgemeiner Teil, Sachenrecht, Familienrecht, Wien, 2006. 570 p. (In Germ.).

27. Kurzynsky-Singer E., Zarandia T. Rezeption des deutschen Sachenrechts in Georgien. Max Planck Private Law Research Paper. 2014. Issue 14/10. Pp. 107-138. (In Germ.).

28. Michael P. Vandenbergh. The Private Life of Public Law. Vanderbilt University Law School Public Law and Legal Theory Working Paper. No. 05-16. Available at: http:// ssrn-id729363 (accessed 12.01.2018). (In Eng.).

29. Münchener Kommentar zum Bürgerlicher Gesetzbuch. 4. Auflage. Band 6. Sachenrecht. § 854-1296. München, 2004. 2628 p. (In Germ.).

30. Ostrom E., Hess Ch. Private and common property rights. Encyclopedia of Law and Economics. 2007. Available at: http://ssrn.com/abstract=1304699 (accessed 12.01.18). (In Eng.).

31. Schwab K.H., Prütting H. Sachenrecht. 32 Auflage, München, 2006. 379 p. (In Germ.).

32. Smith J. Ch. Some preliminary thoughts on the law of neighbors. Georgia Journal of International and Comparative Law. 02/17/2012. 
Available at: http://ssrn.com/abstract $=2054732$ (accessed 12.01.2018). (In Eng.).

33. Snow N. Accessing the Internet Through the Neighbor's Wireless Internet Connection: Physical Trespass in Virtual Reality. Nebraska Law Review. Vol. 84:1226. Available at: http://ssrn. com/abstract $=\mathrm{id} 907842$ (accessed 12.01.18). (In Eng.).

34. Tripp J. Neighbor Law. Oregon Live. (Reprinted from: The Oregonian. September 9, 1991). Available at: https://www.portlandoregon1991.gov/trees/article/528109 (accessed 12.01.2018). (In Eng.).

35. Vieweg K., Werner A. Sachenrecht. 3. Auflage. Köln, München, 2007. 664 p. (In Germ.).

\section{References in Russian}

1. Багаев В. Общему имуществу ищут особую судьбу. Законопроекты о садоводстве и о продаже долевой собственности не поддержаны Советом по кодификации. URL: http://Zakon.ru. (дата обращения: 12.01.2017).

2. Бочаров М. В. Проект Гражданского кодекса: оборот недвижимости в опасности // Юрист. 2012. № 10. С. 21-28.

3. Виниченко Ю. В., Асланян Н. П., Поротикова O. А. Соседское право в России: исторические начала и подходы к пониманию. М.: Юриспруденция, 2014. 152 с.

4. Гражданское уложение. Книга третья: Вотчинное право. Проект Высочайше утвержденной Редакционной Комиссии по составлению Гражданского Уложения. С объяснениями. Т. 1. Ст. 1-174. СПб., $1902.630 \mathrm{c}$.

5. Ельямевич В. Б. Право участия частного и его защита // Вестник гражданского права. 2014. № 2. C. 18-35.

6. Емелькина И. А. Институт ограничения права собственности в пользу соседей (соседское право) в российском праве и в праве отдельных европейских стран // Вестник гражданского права. 2016. Т. 16, № 2. C. 79-112.

7. Живов А. А.О соседском праве и предиальных сервитутах // История государства и права. 2012. № 2. С. 21-24.

8. Концепциия развития гражданского законодательства Российской Федерации: одобр. Советом по кодификации гражд. законодательства Рос. Федерации при Президенте Рос. Федерации 7 окт. 2009 года // Вестник Высшего Арбитражного Суда Российской Федерации. 2009. № 11. С. 6-99.
9. Королев С. В. Экологический императив sine qua non цивилистики XXI в. // Экологическое право. 2010. № 2. С. 33-36.

10. Краснова Т. С. Принудительность и автономия воли в сервитутном праве: дис. ... канд. юрид. наук. СПб., 2017. 263 с.

11. Крассов О. И. Право собственности на землю в странах Европы. М.: НОРМА, 2014. $400 \mathrm{c}$.

12. Курдиновский В. И. К учению о легальных ограничениях права собственности на недвижимость в России. Одесса, 1899. 396 с.

13. Маркин С. В. Совершенствование правового регулирования права собственности на земельные участки // Правовые вопросы недвижимости. 2012. № 2. С. 21-24.

14. Нюкянен П. Приобретение земли и строительство в Финляндии / пер. И. Прилежаева. Союз провинции Этеля-Карьяла, Кюменлааксо, Этеля-Саво. СПб.: Пуна Муста, $2009.159 \mathrm{c}$.

15. Право собственности: актуальные проблемы / отв. ред. В. Н. Литовкин, Е. А. Суханов, В. В. Чубаров. М.: Статут, 2008. 731 с.

16. Суханов E. A. Вещное право: науч.-познават. очерк. М.: Статут, 2017. $560 \mathrm{c.}$

17. Чубаров В. В. Проблемы правового регулирования недвижимости. М.: Статут, 2006. $336 \mathrm{c}$.

18. Хвостов В. М. Система римского права: учебник. М.: Спарк, 1996. 522 с.

19. Шершеневич Г. Ф. Учебник гражданского права [изд. 1907 г.]. М.: Спарк, 1995. 556 с.

20. Doskow E., Guillen L. Neighbor Law: Fences, Trees, Boundaries \& Noise. Berkerly CA: Nolo Press, 2017. 355 p.

21. Eric T. Freyfogle. Property rights, the market, and environmental change in twentiethcentury America // Illinois Public Law and Legal Theory Research Papers. Series Research Paper. 2001. Issue 00-01. November. URL: http://ssrn.com/abstract=id907842 (дата обращения: 12.01.2017).

22. Finck M., Ranchordás $S$. Sharing and the city. URL: http://SSRN-id2741575 (дата обращения: 12.01.2017).

23. Gierke O. Deutshes Privatrecht. Zweiter Band. Sachenrecht. Leipzig, 1905. $598 \mathrm{~s}$.

24. Iro G. Bürgerliches recht. B. IV. Sachenrecht. Dritte Auflage, Wien, New York, 2008. $270 \mathrm{~s}$.

25. Jordan C. Neighbor Law: Fences, Trees, Boundaries \& Noise. Berkeley, CA: Nolo Press, 1998. 352 p. 
26. Koziol H., Welser R. Grundriss des burgerlichen Rechts. B. 1. Allgemeiner Teil, Sachenrecht, Familienrecht. Wien, 2006. $570 \mathrm{~s}$.

27. Kurzynsky-Singer E., Zarandia T. Rezeption des deutschen Sachenrechts in Georgien // Max Planck Private Law Research Paper. 2014. № 14/10. S. 107-138.

28. Michael P. Vandenbergh. The Private Life of Public Law // Vanderbilt University Law School Public Law and Legal Theory Working Paper. Number 05-16. URL: http://ssrnid729363 (дата обращения: 12.01.2017).

29. Münchener Kommentar zum Bürgerlicher Gesetzbuch. 4. Auflage. Band 6. Sachenrecht. $\S \S 854-1296$. München, 2004. 2628 S.

30. Ostrom E., Hess C. Private and common property rights // Ostrom_Hess_Encyclopedia of Law Economics. 2007. URL: http://ssrn. com/abstract=1304699 (дата обращения: 12.01.2017).
31. Schwab K. H., Prütting H. Sachenrecht. 32 Auflage, München, 2006. 379 s.

32. Smith J. C. Some preliminary thoughts on the law of neighbors // Georgia Journal of International and Comparative Law. 2/17/2012. URL: http://ssrn.com/abstract=2054732 (дата обращения: 12.01.2017).

33. Snow $N$. Accessing the Internet Through the Neighbor's Wireless Internet Connection: Physical Trespass in Virtual Reality // Nebraska Law Review (Vol. 84:1226). URL: http://ssrn. com/abstract=id907842 (дата обращения: 12.01.2017).

34. Tripp J. Neighbor Law. Oregon Live All rights reserved - reprinted from The Oregonian. 1991. September 9. URL: https://www.portlandoregon1991.gov/trees/article/528109 (дата обращения: 12.01.2017).

35. Vieweg K., Werner A. Sachenrecht. 3. Auflage. Köln; München, 2007. 664 s. 